M. M. Rohozha, Doctor of Philosophical Science, Professor

Taras Shevchenko National University of Kyiv

60, Volodymyrska Street, Kyiv, 01033, Ukraine

\title{
PHILOSOPHER IN SPACE AND TIME OF CULTURE (CHRONOTOPE OF MAÎTRE À PENSER) PART II
}

The paper deals with the research of philosophic way of life as an invariant of the Western culture. The author tries to reveal the answers to the questions: What is the influence of the time and place of life on a thinking person? Is it possible to put a question in such a way?

The second part of the paper givse methodological explanation for such putting the questions. Two conceptual strategies of thinking in the contemporary history of philosophy are mentioned - compartmentalism and biographical method. The latter one allows understanding of the philosophizing through research of maitre à penser. Such approach made possible cultural studies prospect for a philosopher's life in the context of unique time and space. To designate the uniqueness of time and space, the category of chronotope (M. Bakhtin) was introduced in the paper. Chronotope sets condensed signs in a definite period of time at the result of which a unique image of a thinker is born in a definite cultural space.

Uniqueness of time and space sets originality of philosophical quest of a thinker. Analysis of one's philosophizing through the prism of one's life allows us to compare proved and practiced dimensions, and affirm a status of "maître à penser", if these dimensions are coincided.

The second part of the paper is focused on the time and space of the epoch of Modernity, where public space of the city as a place of activity for a philosopher is inseparably linked to critically directed an self-organized general public. Special attention is focused on life activity of Albert Schweitzer and Hannah Arendt. The author concludes that unlike Antiquity and Middle Ages where we were focused on the images of philosophers, Modernity deals with personalities of philosophers. Schweitzer as well as Arendt personally testify to their life and philosophical practice. The point is that definite life experience according to personal philosophy is purely important moral milestone, transforming the person to worthy exemplary.

Key words: philosopher, public sphere, general public, scientist, maître à penser, Albert Schweitzer, Hannah Arendt, service to people, Western intellectual tradition, spiritual exercises

Удк: 130.2

I. A. Sajtarly, Doctor of Philosophical Science, Professor Taras Shevchenko National University of Kyiv 60, Volodymyrska Street, Kyiv, 03022, Ukraine Inna.saitarly@gmail.com

\section{A FEW NOTES ON FUNDAMENTAL APPROACHES IN THE POSTMODERN THEORIES OF CULTURE}

This article is devoted to a complicated problem in the postmodern philosophy of culture, within framework of that there is ambiguous attitudes to understanding of cultural field. On the one hand, the postmodern thinkers criticize the traditional culture, which in their opinion is based on repressions and violence. On the other hand, they reject the current system of values because they consider it to be decadent in relation to both humans and society. It should be concluded from this philosophy, that in the role of "schizoid subject", in contrast with postmodernist arguments, we have reached a limit not for capitalism, but mainly for culture.

Key words: Oedipus complex, unconsciousness, schizoid subject, anthropological type, phantasm, desiring-production.

Introduction. The problem of dissolution of both human culture and human being is most painful problem in postmodern thinking. This issue is connected to looking for major reasons of cultural decadence that is seen in the high-development post-industrial society. I'm referring to the rising of transgression, cult of destruction and consumption, violence etc. All this testifies to the weakness of the present institutes of culture and social relationships.

Methodology of this research is based on philosophical strategies that was proposed by leading thinkers of XX century, for instance, by Jean Baudrillard, Gilles Deleuze, Felix Guattari and other. It refers to the critical review of psychoanalytic theory culture that arose, as well known, on psychoanalytic basis, for example, the "Schizanaliz" of Guattari and Deleuze.

My main intention of this research is to exposit that critical review of the theory culture in some postmodern texts, which are based on political and economic argumentations that are due to reflection of profound transformation in current societies.

The exposition of main ideas. What's connection between so well known, but completely different strategies in socio-cultural theories like psychoanalysis, structuralism and so-calling post-structuralist approaches of Postmodernity? The answer is more than obvious. All of them tend to treat culture as the most important component of any society actualization. This concerns for only that culture, which structural core is a highly developed system of ethical standards. How true is this statement, and what indeed takes place at the postmodern "factory" of thinking?

There is one more thing that is related to these approaches very closely. I am referring to general line, which has been sketched by $Z$. Freud in his well known "Totem and Taboo" essay. In these notes, the famous researcher articulates complicated problems. Some of them are unsolved up to now. For instance, the problem of so calling primary "displacement" that in orthodoxly psychoanalysis is directly linked to function of the Oedipus complex. The topic or "narrative" of Oedipus complex has united many modern and post- modern thinkers. However, some of them either reject this concept, or demonstrate an attempt to resolve the difficulties, formulated in Freud's theory of culture.

Let's recall the sharp discussion, started by C. LéviStrauss within structuralist framework in relation to the Oedipus complex. Lévi-Strauss was the first thinker, who made firm doubt of the Oedipus complex existing in condition of primitive or so-called "barbaric" society. In addition, here is another essential issue that is directly related to this topic. This is matter of the affections emergence, corresponding to socalling "affective values" as the values of human relations. Starting with G. Jung, in the modern psychoanalytic thought such theme as a "castration phobia", for example, was replaced by the theme of affective structures. However, later in postmodernist studies the topic of affective values was substituted by the topic of schizophrenia. Why did it happen?

The founder of psychoanalysis was known to be convinced that the stable emotional attachment is a direct affective basis of internalization, for example, familial ethic, parental duty, romantic love, etc. Though, Freud was also convinced in major role of castration phobia in actualization the moral consciousness. On the one hand, the mental characteristics mentioned above were considered by him to be relative, caused by cultural peculiarities of historical epochs or societies. On the other hand, Freud believed that immanent structure of human unconsciousness is to be relatively unchanged because it depends on the "father complex".

For instance, in his famous "Totem and Taboo" work Freud claimed, "that the totem animal is really a substitute for the father". He was sure in the idea of common father, hence the Oedipus complex had been already inherent to the primal human society. From his point of view, already at that time "the group of brothers, banded together were dominated by the same contradictory feelings towards the father, which we can demonstrate as the content of ambivalence of the father complex in all our children and in neurotics. They hated the father who stood so powerfully in the way of their sexual demands and their desire for power, but they also loved and

() Сайтарли I. А 
admired him. After they had satisfied their hate by his removal and had carried out their wish for identification with him, the suppressed tender impulses had to assert themselves. This took place in the form of remorse, a sense of guilt was formed which coincided here with the remorse generally felt. The dead now became stronger than the living had been, even as we observe it to-day in the destinies of men" [3, p.166].

Thus, Freud supposed that such structure as the Oedipus complex was already in the primitive mind and insisted on significant meaning of human attachment in it. I am referring to Freud's hypothesis of "sense of love" and "sense of guilt" as a reaction to the supposed killing of despotic leader in primitive society. This moral component is considered to be main function of the Oedipus complex, next to the castration phobia. Later, this discussion will be continued within the issue concerning the origins of human culture, in which the so-called "affective values" play a major role.

The thing is that according to some modern experts the so-called "father complex" has indeed a double face. In other words, the opposite feelings coexist there - profound emotional attachment and hatred with its identical direction to parents. Some scientists have reached the conclusion that the Oedipus complex act not on its natural but on affections basis, expressed in human needs of love or care, the absence of which can lead to negative psychological reaction. In comparison to the castration phobia - that is, to "the fear of losing penis" or refusal of a passive attitude, the phobia of losing a parent's love, probably, is proved to be more effective within internalization of moral norms.

As we find out later, not only the narcissus feels total indifference to the family, society etc. The schizophrenic, as Guattari insisted reasonably, is also essentially beyond the Oedipus complex, thus occupying an absolutely antifamily position. That is why Freud, as we know, couldn't stand the narcissistic persons and the schizophrenics. Such an attitude of him is quite understandable.

Postmodernist philosophes, such as Guattari, claim that today we should first of all find out what the Oedipus complex means. As is well known, Guattari finally reached the conclusion about its artificial character. However, it seems that, on his point of view, all emotional attachments are considered as fake. Is that why postmodernist philosophes focus their attention on the Schizophrenic Subject?

Sertainly, in a famous book of the $X X$ century, named "Anti-Oedipus. Capitalism and Schizophrenia" F. Guattari writes that the Oedipus complex is the "shame image" by its nature, and so the first analysis is "or should be, so impersonal that so-called human relation are not involved". Then he proposes interesting but quite debatable exposition of his views and claims that, in spite of dominant experience of communications between parents and their child, the first relationship is neither personal, no biological - a fact which, from his view, "psychoanalysis has not succeeded in grasping".

The post-structuralism criticizes the "orthodox psychoanalysis", referring to hypothetical experience of the primary "innocence desiring-production", which ostensibly is only human one. While the psychoanalysis talks about the formation of the human personality, which a priori resists idiocy of desire, that is - about such a psyche that even an animal cannot be attributed. For even an animal is controlled by something, for example, by instinct.

Meanwhile, it seems to me, this criticism in some sense is quite justified, because it is based on really profound changes in structure of human psyche of the post-industrial era, and consequently on the appearance of new anthropological type human being, which scarcely feels need of emotional attachments. In any case, it is difficult to deny that current "human being", named by Guattari as "schizoid", is no longer "madman of family". Probably that he has schizoid unconsciousness in the sense of unlimited production of phantasms or, as philosophes claim, desiring-production. Such unconsciousness, as postmodernists note, "always is an orphan", and "it has engendered itself in the identity of nature and man".
Hence, here, contrary to "orthodox psychoanalysis", the human desire is not to be reduced to the genital function, and the human unconsciousness should not be regarded as only Oedipal in its content. G. Deleuze, for example, sarcastically remarks that "by placing the distorting mirror of incest before desire (that's what you wanted, isn't it?), desire is shamed, stupefied, it is placed in a situation without exit, it is easily persuaded to deny "itself" in the name of the more important interests of civilization" [2, p.118].

Not only postmodern philosophes, but also many other thinkers insist that human desire has social nature in the meaning of its depending on dominated system of public relations, which exists, as Guattari points out quite reasonably, from the very beginning of emergence of social production and reproduction. According to meta-anthropology offered by the post-structuralists, a person in current time is neither spiritual, nor social in terms of his complete indifference to person relationships. Here is how Guattari writes about this indifference: "would seem that certain subjects have such a viscous libido or on the contrary such a liquid one that nothing succeeds in "taking hold"'" [2, p.85]. These sentenced the whole humankind, which has not any high values anymore. Hence, the issue of sublimation, that is, - of the culture with its topic of affective values are closed here.

In other words, one can agree with authors mentioned above that the anthropological type, which has arisen recently, is rather a "desire machine". "Cynicism has said, or claimed to have said, everything there is to say about love: that it is a matter of a copulation of social and organic machines on a large scale (at bottom, love is in the organs; at bottom, love is a matter of economic determinations, money") [2, p.292].

Unfortunately, such a point of view concerning relationships in postmodern society belongs to many postmodern philosophers. Even J. Baudrillard, whose attitude to the "body without organs" concept was quite skeptical and also, in spite of his doctrine about postmodern culture as an "orgiastic" one, had to provide diagnosis to its "death" or consider it in the terms of "carnivorous erotic ideology" of "mutants, transvestites, genetically baroque beings whose conceals their genetic lack of specificity"[1, p.21].

It is emphasized in recent investigations that the postmodern human being has become absolutely anti-family oriented, anti-natural or contra-natural, and therefore some postmodern philosophers willingly use such concept as the "body without organs". As postmodernists write, "the body without organs" is a major attributive characteristic of schizoid that is opposite to paranoid Oedipus, gendering "from the stasis of libidinal energy - that actualizes Oedipus and engages desire in this requisite impasse, organized by the repressive society" [2, p.163].

To Guattari's view, institution of family is indeed a delegated agent of this psychic repression, insofar as it ensures the psychological reproduction of economic system of a society. Meanwhile, the postmodern culture that is correlated to postindustrial society, tends to the dissolution of close relations, attachments, and stable family, at the same time, it is characterized by the powerful economic pressure that has never existed before. The thing is not only about the schizoid unconsciousness, but also about the cult of desiring-production. It is so due to functioning of repressive production system possible because of Oedipus actualization. Above the sexual libido that is a primary structure of psychic, have being built such desire, which by its nature is economic or political one. This mainly refers to desire of money and power that doesn't need sublimation. This is the way to generate a paranoiac-fascist, which invests the formation of central political economic system, "over invests it by making it the final eternal cause for all the other social forms of history".

According to logic of "schizoanalysis" libido originally to designate the specific energy of desiring-machines that is not aggressive, but it is anti-social. Schizoid is absolutely indifferent to any social order. Thus, such subject demonstrates his true attitude, when he completely rejects the family and the whole field of social relations and "retreat into his shell". To hell with mother, father, family and affections! Yet the paradox of schizophrenia lies in the 
fact that it is the product of capitalism, hence such social order, as Guattari claims, provide "familialism" and at the same time, schizophrenia is the bound of capitalism, its limit.

Postmodernists emphasize that identity of capitalism and schizophrenia belongs to almost all subjects of current production process in the meaning that each of them is fascinated by "desiring production": "Monetary flows are perfectly schizophrenic realities, but they exist and function only within the immanent axiomatic that exorcises and repels this reality. The language of a banker, a general, an industrialist, a middle or high-level manager, or a government minister is a perfectly schizophrenic language, but that functions only statistically within the flattening axiomatic of connections that puts it in the senvice of the capitalist order" [2, p.246].

The reader can get ambivalent impression concerning a theory that was mentioned above. Nevetheless, the postmodernists insist that every society is totalitarian, even capitalist one, in which elites are always intending to get an absolute power in relation to social lower classes. Their aim to annihilate any desire that is not corresponding to the interests of régime, or it has not been sanctioned by the whole society. For realization of this aim, elite uses different means - from blooded shows to ideological approaches, for example, religion or mass media. In a word, any state in its essence is "despotic". That is why State has been forming such a public consciousness that reflects the interests of ruling class, and that is why F. Nietzsche once said his famous phrases: "churches, armies, states - which of all these dogs wants to die?"; "It could be that, spiritual or temporal, tyrannical or democratic, capitalist or socialist, there has never been but a single State, the State - as dog, that speaks with flaming roars". [2, p.132]. On the other hand, the postmodernist "schizoid alternative" is somewhat troublesome, because it is not only madness or, as was said above, "the limit of capitalism", but also a dread negation of culture in all its meanings.

Indeed, the postmodern culture, not accidently named as "aesthetic", doesn't bring limits to anything. Moreover, the traditional culture, which psychoanalysis considered (and which indeed could be defined) as a repressive one, compulsive and "blooded", today is completely dead. In the conditions of postmodern culture with its "desiring-production", "desiring consumption" and finally, with its cult of "transgression", the social relations are considered to be so weak that it generates a lot of social, moral and psychic troubles.

Probably, the "Anti-Oedipus. Capitalism and Schizophrenia" should be seen as a serious provocation. Its task is to reconstruct a production system in the conditions of industrial capitalism and anthropologic type that is correlated to it. Obviously, this book reflects a burning hatred of people, family, and society, where human relations are replaced by "flows", "environments" and "objects".

At first sight, it seems that the authors of this project do not see special difference between the functional field of culture and the capitalist economy because, from their perspective, the culture and capitalism are based on repression. The negative analysis of culture prevails here. However, postmodern philosophers also insist that capitalist system of production has substituted the cultural code for axiomatic of abstract quantity in mode of money. It means that the capital destroys the cultural code as such, assigning it only an archaic, folkloric function, etc.

Results. One can agree partly that between the culture and production function some identity can be found, but only in their repressive meaning. The culture and economy always significate the "compulsion". Nevertheless, it should not be concluded from this that we are talking about the same com- pulsion. The repressiveness of the culture is meant to be the forcing to normal conduct or the law, but in case of capitalism, the thing is about its forcing to production and then - to consumption. In this connection, as J. Baudrillard reasonable noted, in the conditions of post-industrial economics, the labor should not be considered as a symbol of compulsion anymore, but rather - as value that significates the "gift", or "ack". Moreover, in the system of post-industrial economic the productive labor lost its true meaning that is direct cause of substituting the immaterial production for the material one.

Today we observe not only the lack of labor in its different senses, but also the lack of culture in its ability to regulate the relationships. Is the human society without law functioning, that postmodern thinkers hated so much, possible anyway? Indeed, the constant attribute of "Western" civilization is permanent evolution of production area, and postmodern philosophy is an immediate reflection of the finale stage, named "post-industrial society". One can get an impression that traditional problem of so-called "civilizational approach" is ignored here. In other words, problem of the primary of existential values, that is - cultural one, or determining role of the economic "basis" in many postmodern investigations is replaced by the problem of dissolution of any cultural tradition, defined as "decoding". Postmodern philosophes emphasized that the structural matrix of the post-industrial civilization is different because it is dominated not by social, but by political economy institutions, that reflect the interests of global capital, its cruel struggle for productive resources and domination in world markets. All the rest is at the mercy of an all-powerful and indestructible simulacrum, therefore, a continuously broadcast lie, produced in the virtual space, as long as it is interesting. This led, of course, to the nonstop production that finally was extrapolated on unconsciousness, where reality was replaced by the simulacrum. Henceforth the immediate component of the unconscious is a "phantasms", which is correlated to simulacrum, but desiringproduction is directly corresponded to production of desire - anyone, even most vile, disgusting, low and inhumane.

Discussion. Thus, the "economy or culture" dilemma, which is inherent to philosophy of the XX century, is turning today into an indistinguishable union, where the economy occupies the dominate position. It became obvious that the existence of society in its whole is impossible beyond culture. The aim of culture is to restrict the capitalism by adjusting social life, including the production area.

\section{REFERENCES/ СПИСОК ВИКОРИСТАНИХ ДЖЕРЕЛ}

1. Baudrillard J Transparency of Evil. Essays on Extreme Phenomena; Translated by James Benedict] / J. Baudrillard - London-New York: Verso 1993. - 173 p.

2. Deleuze G. Guattari F. Anti-Oedipus. Capitalism and Schizophrenia; [Translated by Robert Hurley, Seem Mark, and Helen R. Lane] / Gilles Deleuze and Felix Guattari. - Minneapolis: University of Minnesota Press, 1983. - 400 p.

3. Freud S. Totem and Taboo. Resemblances Between the Psychic Lives of Savages and Neurotics [Authorized English Translation, with Introduction by A. A. BRILL, Ph.B., M.D. Asst. Prof. of Psychiatry, N.Y. PostGraduate Medical School; Lecturer in Psychoanalysis and Abnormal Psychology]. - New York University; London: GEORGE ROUTLEDGE \& SONS, LIMITED, 1919. Retrieved from http://www.gutenberg.org/ebooks/41214

$$
\text { REFERENCES (APA) }
$$

1. Baudrillard, J. (1993). Transparency of Evil. Essays on Extreme Phenomena. London-New York, Verso.

2. Deleuze, G. Guattari, F. (1983). Anti-Oedipus. Capitalism and Schizophrenia. Minneapolis, University of Minnesota Press.

3. Freud, S. (1919). Totem and Taboo. Resemblances Between the Psychic Lives of Savages and Neurotics. New York University; London: GEORGE ROUTLEDGE \& SONS, LIMITED. Retrieved from GEORGE ROUTLEDGE \& SONS,
http://www.gutenberg.org/ebooks/41214

Received Editorial Board 01.10.17

И. А. Сайтарлы, д-р филос. наук, профр.

Киевский национальный университет имени Тараса Шевченко

ул. Владимирская, 60, г. Киев, 03022, Украина

\section{НЕСКОЛЬКО ЗАМЕТОК О ФУНДАМЕНТАЛЬНЫХ ПОДХОДАХ В ПОСТМОДЕРНИСТСКИХ ТЕОРИЯХ КУЛЬТУРЫ}

Эта статья посвящается сложнейшей проблеме в постмодернистской философии культуры, в рамках которой сложилось двусмысленное понимание культурного поля. С одной стороны, постмодернистские мыслители критикуют традиционную культуру, которая, с их точки зрения, основана на репрессиях и насилии, а с другой - они отвергают существующую систему ценностей, поскольку считают ее декадентской по отношению к человеку и его обществу. Из этой философии можно сделать вывод, что в ипостаси "шизоидного субъекта", в противоположность постмодернистским аргументам, мы, по большому счету, достиели предела культуры, а не капитализма.

Ключевые слова: комплекс Эдипа, бессознательное, шизоидный субъект, антропологический тип, фантазм, желающее производство. 
І. А. Сайтарли, д-р філос. наук, проф.

Київський національний університет імені Тараса Шевченка вул. Володимирська, 60, м. Київ, 03022, Україна

\section{ДЕКІЛЬКА НОТАТОК ЩОДО ФУНДАМЕНТАЛЬНИХ ПІДХОДІВ У ПОСТМОДЕРНІСТСЬКИХ ТЕОРІЯХ КУЛЬТУРИ}

Статтю присвячено складній проблемі постмодерної філософії культури, в рамках якої склалося двозначне розуміння культурного поля. 3 одного боку, постмодерністські мислителі критикують традиційну культуру, яка, з їхньої точки зору, заснована на репресії і насильстві, а з іншого - вони відкидають чинну систему цінностей, оскільки вважають її декадентською стосовно людини та її суспільства. Тому, на противагу постмодерністським аргументам, з цієї філософії можна зробити висновок, що в іпостасі "шизоїдного суб'єкта" ми досягли, головним чином, межі культури, а не капіталізму.

Ключові слова: комплекс Едипа, несвідоме, шизоїдний суб'єкт, антропологічний тип, франтазм, бажаюче виробництво.

УДК 130.2

В. А. Сіверс, д-р фрілос. наук, профр. Національна академія керівних кадрів культури і мистецтв вул. Лаврська, 9, Київ, 02000, Україна nok55@ukr.net

\section{ЕМУЛЯЦІЯ І ЖЕРТВА (ДО АНАЛІЗУ ЦІННІСНОГО АСПЕКТУ СТВОРЕННЯ ШТУЧНОГО ІНТЕЛЕКТУ В МОДЕЛІ НІКА БОСТРОМА)}

Актуальність теми визначена прогнозами філософрів і футурологів щодо наближення стану сингулярності, чинником якого є створення штучного інтелекту (Шال). Стаття присвячена розгляду філософсько-аксіологічних аспектів розвитку Шا у зв'язку з проблемою "завантаження цінності" Ніка Бострома та необхідністю врахування ціннісного вектора, тематизованого у статті в понятті "жертва". Якщо свідомість може бути представлена як здатність відображення, а поява життя неможлива без реплікації, тобто самокопіювання, то розвиток такого уявлення передбачає, що копіювання відбувається знову і знову, але не повністю, не-довершено, тобто на іншій основі. Зміна цієї основи означає можливість втрати наявного існування як результату діі механізма самокопіювання й окреслює можливість уведення поняття "жертва". Метою статті є обґрунтування на основі феноменологічного підходу, методу аналогії та комплексного аналізу перспективного висновку, що дослідженням ШІ слід надати можливість розвиватись вільно і без обмежень, а людині слід забезпечити умови такого дослідження, що у перетвореній формі маніфестує етапи жертовного руху людини до невідворотного результату "завантаження цінності" у певну імітаційну систему.

Ключові слова: сингулярність, штучний інтелект, аксіологія, жертва, завантаження цінності, завантаження жертви, копіювання, переживання, смисл.

Постановка проблеми. Теза, що виражає у широкому формулюванні актуальність і вказує на проблему, що виявляється та розглядається у межах даного матеріалу, визначається онтологічними чинниками. Вона полягає у твердженні, що на теперішньому етапі пізнавальної і практичної діяльності людини наближається така точка зламу, коли питання найбільш загального плану, що у попередній пізнавальній традиції було прийнято відносити до суто філософських, тобто таких, що постійно відтворюються у новій формі та постановці на наступних історичних щаблях, але остаточно ніколи не вирішуються, отримують своє радикальне вирішення не стільки шляхом побудови пізнавальної моделі явища, скільки внаслідок "дозрівання" кількісних і якісних умов універсального розвитку людини як родової істоти. Згадане "дозрівання" може розглядатись як завершений стан, що у сучасній філософськокультурологічній та науково-технічній термінології позначено як "сингулярність". У масовій культурі технологічна сингулярність, на думку Рея Курцвейла, означає таке гіпотетичне майбутнє (за різними прогнозами, від 2029 до 2047 рр.), коли обчислювальні можливості комп'ютера перебільшать можливості людського мозку. Вважається, що після цього моменту передбачення (тобто будь-який прогноз, що і становило фактично смисл пізнання до цього моменту історії) втрачають сенс і стають безглуздими. "Дозрівання" в тематичному контексті даної статті осмислюється як дискурс з проблем ШІ, який в теоретичному аспекті розвивається як спроба передбачення, аналізу і моделювання шляхів і наслідків розвитку ШІ, а як практика такого створення окреслюється смислами та значенням поняття емуляція (та симуляція, яка в даному контексті не розглядається). Згідно з канонічним визначенням, емуляція (англ. - emulation) в обчислювальній техніці - це комплекс програмних апаратних засобів або їхне поєднання, що призначене для копіювання (або емулювання) функцій однієї обчислювальної системи (гостя) на іншій, що відрізняється від першої таким чином, щоб емульована поведінка якомога ближче відповідала поведінці оригінальної системи (гостя). Метою $є$ максимально точне відтворення поведінки на відміну від різних форм комп'ютерного моделювання, у яких імітується поведінка якоїсь абстрактної моделі. Однак процес створення та розвитку Ш не є суто технічним чи технологічним завданням. Якщо у загальному плані сформулювати глибинний культурно-фрілософський аспект проблеми, а саме поставити питання, що надихає і що спонукає людину намагатись копіювати себе, то не можна обмежуватись тільки поверховою вказівкою на бажання нескінченно створювати нові та удосконалювати наявні засоби виробництва та знаряддя праці начебто у спробах поліпшити умови життя. Потрібно звернути увагу, що спроби створення Ш знаменують фракт, що базується на принципово контраверсійній відносно панівної в історичній людській свідомості позиції щодо вторинного характеру природи людини і її походження, яке цілком є результатом Божого задуму і творіння або результатом діяльності інших надлюдських сил. Цей аспект, що не часто розглядається у контексті даної теми, i постає джерелом дослідницьких інтенцій у статті. У новітній період історії, коли створення Ш постало як досяжна мета, особливої актуальності набуває розгляд саме етико-філософсььих та соціо-антропогенних її аспектів.

Аналіз досліджень і публікацій. Можна вважати, що початок осмислення проблеми розвитку Ш у сучасний період позначено статтею А. Тьюрінга 1950 року "Обчислювальні машини та розум", де пропонувався тест, згідно з яким машина мислить, якщо людина не може в результаті діалогу наосліп визначити, що вона спілкується з машиною. За час удосконалення практичних аспектів розробки і створення Ш проблема набула соціо-культурного та етико-філософрського значення і тепер щільно поєднується 3 проблематикою трансгуманізму та вивченням механізму глобальних катастроф. Серед дослідників її Робін Хансен, Девід Брін, Баррі Дайнтон, Біл Джой, Еліезер Юдковскі, Вернон Віндж, російські вчені та науковці В. Степін, О. Турчин, М. Медвєдєв та ін. Ціннісні аспекти формування Ш досліджує Д. Гаспарян. Серед вітчизняних дослідників проблемам інтелекту у структурі буття присвячено працю Є. Андроса, позитивні та негативні виміри антропокультурного розвитку вивчає В. Загороднюк, аспекти взаємодії смислу та абсурду у культурних артефактах та моделюванні нейронних мереж - О. Довгань. Водночас пряме співставлення технологічно-функціонального й етико-аксіологічного підходу в дослідженні проблеми не було предметом осмислення науковців до останнього часу. 